\title{
Introduction. Migration and Constructions of the Other: Inter-Communal Relationships amongst South Asian Diasporas
}

Aminah Mohammad-Arif and Christine Moliner

\section{OpenEdition}

Electronic version

URL: http://journals.openedition.org/samaj/136

DOI: 10.4000/samaj.136

ISSN: 1960-6060

Publisher

Association pour la recherche sur l'Asie du Sud (ARAS)

\section{Electronic reference}

Aminah Mohammad-Arif and Christine Moliner, «Introduction. Migration and Constructions of the Other: Inter-Communal Relationships amongst South Asian Diasporas », South Asia Multidisciplinary Academic Journal [Online], 1 | 2007, Online since 14 October 2007, connection on 19 April 2019. URL: http://journals.openedition.org/samaj/136 ; DOI : 10.4000/samaj.136

This text was automatically generated on 19 April 2019

\section{(c) (1) $\odot \odot$}

This work is licensed under a Creative Commons Attribution-NonCommercial-NoDerivatives 4.0 International License. 


\title{
Introduction. Migration and Constructions of the Other: Inter- Communal Relationships amongst South Asian Diasporas
}

\author{
Aminah Mohammad-Arif and Christine Moliner
}

1 Since Independence in 1947 and the creation of two separate nation-states, the Indian Subcontinent has regularly witnessed ethnic violence (several wars of varying intensity opposing India to Pakistan in 1948, 1965, 1971, 1999), partitions (1947 and 1971), bloody riots, in which different communities have been confronting each other along various lines: religious (Hindus vs Sikhs, Hindus vs Muslims), ethnic (Punjabis vs Bengalis, Sindhis $v s$ Muhajirs, and so on), and national (Indians vs Pakistanis, Pakistanis vs Bangladeshis). These episodes of violence have at times reached astonishing levels, as during the 1947 Partition when hundreds of thousands lost their lives while millions had to flee what had been the homeland of their forefathers for centuries. This was nothing less than an ethnic cleansing beforehand. In India, ethnic violence has taken on such an importance that a specific word has even been coined to define the tensions between the major ethnic groups, Hindus and Muslims in particular: communalism. ${ }^{1}$ In Pakistan, the creation of a separate country along religious lines has not subsumed other identities, as the 1971 Partition between East and West Pakistan (and the subsequent creation of Bangladesh) has shown: ethnic and linguistic identities were successfully mobilized against an authoritarian centre. These periods of violence have however been (fortunately) followed by longer periods of relative peace and stability, and even 'outright' reconciliation, when tensions and animosities even appeared as a (quasi)-aberration. This was the prevalent mood when India and Pakistan embarked upon their peace process in 2004.

Our interest now lies in the relationships between South Asian ${ }^{2}$ sub-groups in a diasporic ${ }^{3}$ context, while keeping in mind the dominant situations in home-societies as well. Through the exploration of the similarities and differences between the diaspora and the countries of origin on the one hand, between different host-societies where South Asians 
have settled down on the other, we would like to assess whether there is any specificity of the diaspora. Does the situation observed in the diaspora reinforce the theories that are put forward to explain ethnic conflicts and ethnic violence? Or does it on the contrary invalidate them? Are there any internal dynamics, and if so, to what extent are they independent from the events and turmoil of the Subcontinent? These are some of the questions that we will try to address here.

countries have been selected for this study, the United States, the United Kingdom and France. The United Kingdom has long been the paradigmatic country of the migration from the Subcontinent. The United States has become the home of fairly successful and increasingly visible South Asian diasporas ${ }^{4}$ but it also witnessed an event that reshaped its ethnic landscape and its relation with the Other: September 11. As for France, apart from the fact that all the contributors to the special issue are based in France, this country offers a (relatively, see infra) contrasting example with the AngloSaxon model in terms of integration and the place of religion in society.

\section{Migration and identity: diasporic constructions of the Self and the Other}

Migration is often a very disruptive experience that generates a sense of insecurity, resulting from uprooting and marginality. In their adaptation strategies, immigrants redefine their self-perceptions and their collective identities.

Recent scholarship has insisted that collective identities, far from being immutable, are constructed, multiple and flexible. All the contributions to this volume highlight in particular the role of Otherness in fashioning identity. This transactional aspect of identity is reinforced in a context of migration: diasporic constructions of the Other(s) are remarkable for their multiplicity and their instability (see Gayer, Moliner in this volume). In the host country, South Asians interact with other South Asian groups, with different ethnic minorities and with the majority population, who all potentially represent powerful figures of Otherness. And the representations and relationships thus generated are highly instable, as they depend on complex interactions between the global context, the regional (relations between South Asian states), the national (public policies towards ethnic minorities) and even local ones (community relations might not follow the same patterns on the East and the West Coast of the United States or in Bradford and Southall).

Migration tends to reinforce antagonist perceptions of 'us and them', and to strengthen national/ethnic/religious identifications. Peter van der Veer has offered the most comprehensive analysis of the dialectical link between migration and nationalism (Van der Veer 1995). Although nationalist discourse is opposed to expatriation, and to the mixing of population and the transgression of national boundaries it implies, migration fosters nationalism both among the indigenous population (through defensive, xenophobic forms of nationalism) and among migrants, through exacerbated expressions of national identity, defined along ethno-religious lines. In this process mutually exclusive religious nationalisms are fashioned. They are based on a reinvention of the past, on naturalizing the link between people, culture and territory and on antagonist constructions of the others. 
7 In the process of the redefinition of diasporic identities, religion tends to become a major component of ethnic identity. This is due to the disruptive nature of migration that propels some migrants to turn to what they perceive as unchanging values and traditions of their past. This also owes to the political framework of the host society where the ethnicity ${ }^{5}$ of minority groups is mainly defined in religious terms and used as a basis for mobilization and politics of recognition (for the notable exception of France, see infra).

Finally the experience of migration often leads to a self-conscious reflection on religious traditions, beliefs and practices. This redefinition of things religious tends towards rationalization, homogenization, drawing of clear-cut boundaries with other religious groups and exclusion of heteropraxy (popular practices for instance). Interactions with others (indigenous populations, South Asians and other minority groups) prove an important component in this process of redefinition: what was taken for granted at home has to be explained, sometimes advocated in a hostile environment and finally transmitted. The issue of religious and cultural transmission to the next generation is indeed perceived as crucial.

\section{The existing literature}

9 Most studies have so far focused on the relationships between immigrants, their homelands and host-societies, but very few studies deal with the issue of inter-ethnic relationships amongst South Asian diasporas. Among the major exceptions, is the book edited by Crispin Bates (Bates 2001) where several case-studies of inter-ethnic relationships are examined both in the Subcontinent and in the diaspora: ethnicity and community politics in Fiji (Kelly), Mauritius (Nave), East Africa (Twaddle), Trinidad (Chatterjee), Pakistan (Leonard and Waseem) and India (Hansen), to mention a few. Interestingly, no European country has been chosen as a case-study in this otherwise highly interesting book, not even the UK (owing probably to the lack of researchers who have shown any interest in the topic, though the issue of South Asians in the UK as such has been very thoroughly studied by the best specialists). At any rate, as Crispin Bates has underlined in the introduction of the book, many researchers have tended to neglect this issue as they see it as unproblematic:

It is assumed that the identities of migrant communities say Indian Hindus and Pakistani Muslims, male and female, are largely brought with them, and that they are based upon primordial and age-old forms of identity to be found in the Indian Subcontinent. The conflict between these 'communities', and the expression of gender and caste differences, are then often accepted as inevitable or natural, and only their articulation and the choice of methods for their management and amelioration remain a cause for concern. The international activities of militant political and religious organizations such as the $\mathrm{VHP}^{6}$ and the $\mathrm{JI}^{7}$ are likewise predicated upon the assumption that the interests and identities of Hindus and Muslims everywhere are essentially the same (Bates 2001: 2-3).

10 Apart from Bates, Laurent Gayer, a contributor to this volume (see below), has also addressed the issue of inter-ethnic relationships: in his Masters dissertation (Gayer 1998), he draws a comparison between the patterns of relationships between South Asian populations in London and Paris. He shows how diasporic populations can invent a common identity in opposition to the racism of the host-society as is observed in London for instance, while at the same time they can reinvent (and not simply import) the 
conflicts affecting their homelands (Hindu/Muslim communalism, Sikh separatism, and so on).

\section{Inter-ethnic relationships and long-distance nationalism}

11 Apart from a couple of studies, not much has been written on this topic. And yet these diasporas are not only increasingly important at the demographic level (20 million Indians, 4 million Pakistanis, 4 million Bangladeshis) ${ }^{8}$ and more and more diversified, but they are also getting increasingly involved in the politics of both their host-society and their homeland. Besides, as a result of the migration process, many of these immigrants experience a redefinition of their identities (see supra), some identities may become subsumed (like language or caste-based) while others may be given a new salience, and even take precedence over other identities (like religion), which is likely to have implications on inter-ethnic relationships. But such a process can vary from one country of immigration to another, depending on the models of integration prevalent in each country and on other variables, as we shall see below. The fact that the various subgroups often overlap makes this issue all the more interesting and complex. The cases of Indian/Pakistani/Bangladeshi Muslims on the one hand, and of Sikh/Muslim/Hindu Punjabis on the other illustrate it.

Historically, those who have left India have been among the most politicized and defensive of their identities, and have even occasionally indulged in violence. The examples of the Ghadarites in Canada and in the United States at the beginning of the twentieth century, and of the Indians in South Africa, who were the first ones to mobilize against British rule under the leadership of Gandhi, are a case in point (Bates 2001: 8). As for the contemporary period, Benedict Anderson and others have also highlighted that the diasporic experience may generate long-distance nationalism. This is how Anderson defines it (Anderson 1998: 74):

Nonetheless, in general, today's long-distance nationalism strikes one as a probably menacing portent for the future. First of all, it is the product of capitalism's remorseless, accelerating transformation of all human societies. Second, it creates a serious politics that is at the same time radically unaccountable. The participant rarely pays taxes in the country in which he does his politics: he is not answerable to its judicial system; he probably does not cast even an absentee ballot in its elections because he is a citizen in a well and safely positioned in the First World, he can send money and guns, circulate propaganda, and build intercontinental computer information circuits, all of which can have incalculable consequences in the zones of their ultimate destinations. Third, his politics, unlike those of activists for global human rights or environmental causes, are neither intermittent nor serendipitous. They are deeply rooted in a consciousness that his exile is selfchosen and that the nationalism he claims on e-mail is also the ground on which an embattled ethnic identity is to be fashioned in the ethnicized nation-state that he remains determined to inhabit. The same metropole that marginalizes and stigmatizes him simultaneously enables him to play in a flash, on the other side of the planet, national hero.

Interestingly, the sub-group, quoted by Anderson, which is usually given as a quasiparadigmatic example, is from South Asia: indeed, expatriates from the Sikh community have played a significant role in the Khalistani movement (which campaigned for a separate Sikh State carved out of the Indian Union). Moreover, some recent reports have 
shown the important role of migrants, settled in particular in North America and the United Kingdom, in financing religio-political movements in India ${ }^{9}$ while other studies have brought to light that the remittances of Pakistani migrants in the Gulf were partly used to finance religio-political movements in the homeland (Zaman 1998). This implies not only that long-distance nationalism can be observed among all major communities beyond national, ethnic or religious affiliations, but given the heightened sense of nationalism (generated by both endogenous (dislocation leading to insecurity) and exogenous (racism of host-societies) factors) that many migrants experience, it may have implications on inter-ethnic relationships amongst diasporas as well. This also means that in diaspora, along with identities, the inter-ethnic relationships are being redefined, and cannot be simply considered as the replications of the legacy of conflict.

The links that are maintained with home-societies also suggest that many expatriates tend to closely follow the developments in the Subcontinent. Hence some events, like wars, partitions, riots, nuclear tests, destruction of sacred sites, and so on, are likely to have an impact on inter-ethnic relationships in the diaspora. But other events that take place outside the Subcontinent, such as September 11, can also affect these relationships (see Mohammad-Arif, Therwath in this volume).

But beyond transnationalism, it is important as well to examine-through the historical evolution, the mutual perceptions, the organization patterns, and so on-the points of cleavages and of rapprochement between communities. Spaces and vectors of conflict are also worth studying, all the more so as violence as such in the diaspora is first and foremost symbolic. The media, Internet, the lobbies have all a crucial role to play in the process.

\section{The explanations for ethnic violence}

Several theories have been put forth to explain ethnic violence. Ashutosh Varshney's study of the relationships between Hindus and Muslims in India (Varshney 2003) shows that these theories can be classified into five major categories: essentialism, instrumentalism, post-modernism, constructivism, institutionalism. To these, Varshney adds a sixth category, linking ethnic conflict and civil society. He believes that all the former ones are inadequate because they neglect local issues and overlook the importance of civil society.

17 Essentialists explain conflicts by referring to historically deep-rooted animosities based on inherent and irreconcilable differences of race, culture or religion. Hence, ignoring the many instances of cooperation and coexistence between different communities, including Hindus and Muslims who share common conceptions about social life, essentialists argue that their animosities have always existed, and hence that conflicts are inevitable. Essentialism poses a problem not only because of its racialist undertones, but as Varshney underlines, because it also 'makes it hard to explain why, if animosities are historically deep and so rooted in cultural differences, tensions and violence between groups tend to ebb and flow at different times, or why the same groups live peacefully in some places but violently in others' (Varshney 2003: 28).

The instrumentalist argument focuses on how the respective leaderships strategically manipulate ethnicity for the sake of economic and political power (Brass 1991), even though the leaders themselves may not believe in ethnic identity. It does not however 
offer, as Varshney pinpoints, a convincing explanation of why ethnicity is mobilized by the leaders at all. By simply claiming that building bridges may be at times in the interest of the leadership, and creating cleavages in their interest in other instances, it does not make clear why interests can be perceived in totally different ways or why people should blindly follow the leadership (Varshney 2003).

As for post-modernists, they lay the stress on the narratives promoted by the elite, deeply implicated in the formation of knowledge. In the South Asian case, the census is one of the most striking and well-known examples of categorization that has had an incidence on the self-definition of communities (Metcalf 1995). However, its importance in creating separate identities between different communities, mainly Hindus and Muslims, and between castes, should not be over-emphasized as post-modernists have tended to do: categorizations, like census, did not create separate identities as such but certainly helped to crystallize them (Gaborieau 2001).

The constructivist view argues that many of the identities that are taken for granted have in fact been elaborated in recent time (Hobsbawm 1983, Anderson 1983). In a society like India, constructivists, such as Gyanendra Pandey, claim that the main contemporary ethnic cleavages were created by the colonial power and, the impact has been such that their divisions have had a long time effect (Pandey 1990). But once again, if the role of the British in widening the gap between communities cannot be denied, it should not be over-emphasized since, to take once again the examples of Hindus and Muslims, the delimitation of identities, as fluctuating as it could be, was a reality even before the British came to India (it could be observed as early as the thirteenth century); the two communities have even been confronting each other from the seventeenth century onwards (Gaborieau 2001, 2003). Hence the pre-colonial period was not the Golden Age where communal harmony was the dominant norm, as post-colonial literature would have it (Pandey 1990). But the fixation of identities and confrontations, that remained fragmentary and localized (Subrahmanyam 1996: 58), did not mean for all that that these communities nurtured a centuries-old hostility that would have prevented any kind of cohabitation, as the essentialists argue.

21 Last but not least, institutionalism connects ethnic conflict or peace, on the one hand, and political institutions, on the other (Varshney 2003: 35). The nature of multiethnic societies, whether they are consensual (or consociational) ${ }^{10}$ or majoritarian democracies, and have federal or centralized governments, proportional representation or first-pastthe post electoral system, will have an incidence on ethnic peace or conflict. For instance, in a multiethnic society in which ethnic groups are geographically concentrated, federalism may be more suitable for ethnic peace than a centralized political system (Varshney 2003: 38). Although institutionalism is one of the most relevant theories, it does not explain variance in ethnic violence or peace at the local or regional level. Reflecting on this, Varshney suggests a sixth theory, which links ethnic conflict and civil society. For him, only such a framework of analysis can account for local or regional variations. Relying on a thorough study of several cities in India where ethnic conflict has been either recurrent or hardly present, he shows that in cities where there are strong associational forms of civic engagement such as integrated business organizations, professional associations, reading clubs or trade unions, polarization along ethnic lines and outbreaks of ethnic violence are less likely to take place. However, his study, based on statistical data, hardly takes into account power struggles between ethnic groups and between social groups and the State. 
Now it remains to be seen how relevant these theories about ethnic conflict (which may not necessarily be violent) or peace are when applied to the relationships between South Asian communities in diaspora. We have already pointed out their shortcomings in explaining ethnic conflict in home-societies. Interestingly, in a diasporic context, though none of these theories can, in a fully comprehensive way, account for ethnic conflict, almost all of them can be, to some extent, usefully mobilized. Essentialism is not helpful as such for the researcher, but its use by the respective leaderships in creating cleavages (and less frequently in building bridges) between the communities arouses his interest (see below). Given the renewed importance of leadership in a diasporic context (see below), instrumentalism becomes a useful analytical tool. Post-modernism and constructivism can also be useful to understand the existing categorizations put in place in some of the host-societies as they may generate feelings of common belonging, and hence promote ethnic peace (like the 'South Asian' category in the United States or the 'Asian' category in the UK, which 'forcibly' lumps together all South Asians, regardless of their national, ethnic or religious affiliations); these are issues above all of self-perception and self-ascription. In other cases, some people try to differentiate themselves as much as possible from the rest of South Asians (for instance, a fraction of Hindus manifested their difference from other 'Asians', Pakistanis in particular, especially after the Rushdie affair) or from other ethnic groups in the host-society (like Indians trying to look as different as possible from disadvantaged groups such as Hispanics and African-Americans). Last but not least, institutionalism can be summoned to explain that though political institutions as such may not matter in promoting ethnic conflict or peace between the members of a given ethnic group, the 'institutionalized' policy of the host-society towards their minorities (in other words, the models of integration of each country) does have an impact on the inter-ethnic relationships within the group (see below). As for the connection between civil society and ethnic peace, the institutionalist vision is also relevant in that it helps to explain why in countries with strong civil societies, like the United States and the UK, the promoters of ethnic peace can exert an influence on ethnic affairs. But once again, not a single theory can achieve a global and comprehensive explanation. Therefore, we have to rely on a combination of the different models to assess the situation.

\section{The prevalence of local contexts: migration histories, national ideologies and state policies}

The contributions in this volume insist on the prevalence of the different local contexts in extent patterns of relationship among South Asian diasporic communities. In each of the three countries that are studied, France, the UK and the US, a unique combination of historical processes, political ideologies and state policies regarding immigration has fashioned a specific national context and particular ways of dealing with immigration, immigrants and ethno-religious pluralism. The classic opposition between Anglo-Saxon multiculturalism and the French model of republican integration clearly needs to be qualified by taking into account two elements. Firstly, the very different histories of migration in these three countries have been as instrumental as national ideologies in fashioning these two 'models'. Secondly, a convergence of issues and policies related to immigrants is to be observed: multiculturalism is increasingly questioned in the United Kingdom and quotas and affirmative action are being debated in France. 

the arrival of Punjabis on the West Coast, it has become numerically significant much more recently, with a second migration wave that started in the mid-1960s, after the US liberalization of immigration policy. This legislation also privileged educated and qualified people and this explains the very high socio-economic profile of South Asians in the US today -which contrasts with that of their counterparts in France or the United Kingdom. With approximately 3 million people, South Asians amount to $1 \%$ of the total American population.

In the United Kingdom, South Asian migration history owes much to the colonial past: the earliest migrants came as subjects of the British Empire (be they ayah, lascars or princes, see Visram 1986) and so did those who settled en masse in the 1950s, as their status of British subjects was perpetuated within the Commonwealth. A new legislation strictly limiting immigration from 1962 along with a Race Relations policy, which strived at fostering good relations between the different ethnic groups, initiated a second wave of mass migration, mostly made of the wives and children of the 1950s settlers. The majority of them were from unqualified, rural background and they came to the UK as part of a chain migration process. In the 1970s, they were joined by urban, qualified migrants, who mostly arrived from East Africa. Today, with 2.3 million people, South Asians represent the first ethnic group of the country (over $50 \%$ of the ethnic minorities population) and $4 \%$ of the total population, according to the 2001 census.

Asian migrants settled in France came more recently and in much smaller numbers: they came mostly in the late 1970s and now they amount to no more than 130,000. The Pondicherrians represent a special case: thanks to their French nationality, they came much earlier, in the 1950s, after Pondicherry became part of the newly independent India. Amongst migrants directly coming from South Asia, ${ }^{11}$ they constitute the only group having a colonial connection with France. Since the French people have no colonial representation or categorization of South Asians-apart from PondicherriansSouth Asians in France have been subjected to lesser levels of racism and discrimination than North Africans in France or Asians in the UK. Because of the French model of individual integration and because of all these aspects pertaining to a specific migration process, the emergence of well structured South Asian communities in France has so far been delayed.

The historical phases of migration constitute another important variable. Early migrants tended to have more interactions across ethno-religious boundaries for instance: it was the case with the pioneers of the 1930s and 1950s in the UK, with Punjabi Muslims and Sikhs in California in the early $20^{\text {th }}$ century and interestingly with South Asians migrants in Paris today as Chatterji argues in this volume. The nature of migration, whether it is individual or chain migration, is also an important factor in the extent of interactions with the Other. Chain migration, like in the UK, tends to limit the need and the opportunities to interact outside self-sufficient community networks. In France, South Asian migration is composite: while the majority of migrants arrive as part of a chain migration process, a significant proportion do so on an individual basis. As for the United States, most of the migrants in the 1960s and 1970s migrated on the (individual) basis of their qualifications; in the following decades, however, an increasing number arrived thanks to the family reunification provisions, and hence became part of a chain migration process as well. However, South Asians in the United States do not form major ethnic enclaves (except in some areas like Coney Island, in New York, which is largely dominated 
by Pakistanis, or Devon Avenue in Chicago, which has a more mixed South Asian population) and daily interactions with other South Asians tend to be much more limited than in the UK.

The second phase of migration started with the arrival of families, the coming of age of a second generation and the institutionalization of ethnic communities. South Asians in the UK experienced this phase as early as the 1970s. The emergence of a second and now third generation has given rise to a composite and hybrid type of identification as British Asian: as we shall see later, this identity label which transcends the ethno-religious and national boundaries associated with home societies and the parents' generation has become a category ascribed by the dominant society. It is given shape by racism and discrimination and is reappropriated by the youth through the creation and consumption of a common diasporic culture. This phenomenon is much more recent in the US than in the UK and has been reinforced in the aftermath of September 11. As for France, as we have noted, South Asian migration history is still going through the pioneer phase, despite the emergence of a second generation, especially among Pondicherrians, Sri Lankan Tamils and Pakistanis. Interestingly, in the absence of any valid category (SudAsiatique, South Asian, is not used in France and Asiatique, Asian, refers to Chinese and formerly Indochinese people), South Asians tend to be lumped together as Indians or Hindu. Whether this could constitute the nucleus of a common identity remains to be seen.

Finally the place of immigration in national ideologies and the related policies has to be assessed. As is well known, immigration has been central in the definition of the American national identity as the 'nation of all nations'; the country defines itself as a society of immigrants. But very early on, liberal views on immigration coexisted with exclusionist policies. After the Chinese, South Asians were classified as 'aliens ineligible for citizenship' in the early $20^{\text {th }}$ century and the introduction of national quotas in 1924 strictly limited their entry to the country. This period of exclusion, discrimination and xenophobia is an important aspect of the history of the South Asian presence in the US and the post-September 11 period also sheds light on this uneasy past.

Paralleling immigration legislation, the question of integration of these immigrants has emerged as an early preoccupation. In reaction to the predominance of WASP values and principles in the definition of an American identity (even in the melting-pot model), multiculturalism emerged as a new paradigm in the 1960s in leftist circles, under the influence of the civil rights movement. In the multicultural framework that has been operating since then, ethno-cultural identities are to be defended as distinct and equally valued components of national identity. Ethnicity has hence become the only available basis of collective self-definition and mobilization (Lacorne 1997). As the ethnic group constitutes the basic socio-political unit, individuals are encouraged to identify with communities defined on ethno-religious terms. Although official census categories refer to the national origin of immigrants, religious affiliation is prevalent in the definition of ethnic identity.

31 But this is also to be explained by reference to the specific role of religion in the fashioning of American national identity, its relation to the State and its relevance in socio-political debates till today (Lemarchand 1997). Religion has indeed played a crucial role when the country was founded by dissidents of European Protestant churches who had sought refuge from religious persecution. As a result, the American Constitution has established the separation between the State and the Church in such a way that it also 
guarantees freedom of religion and religious pluralism. The American conception of this principle of separation contrasts with the British system of Church and State (since it is opposed to any established religion) and with the French model of laïcité (as it has not emerged out of confrontation with the Church). It is also rather flexible and permeable. Although officially confined to the private sphere, religion is in fact omnipresent in the public space, in social life and political debates. Finally, the American religious landscape, continuously modified and enriched by immigration, is particularly lively since the US has the highest level of religious practice amongst developed countries. The relationship between the State and religion is very different in the UK: the Church of England is the official Church of the State, according to the Establishment Act of 1701. For a long time, it meant that Catholics and Dissenters were denied freedom of religion and were prevented from holding any public office. British modern history is thus characterized by the interdependence of politics and an established religion (and the subordination of the latter to the former) and by religious conflicts between Catholics and Protestants on one side and Anglicans and Dissenters on the other (Baubérot \& Mathieu 2002). As stated by Baubérot and Mathieu, religion has remained an integral part of the country's cultural identity well into the $20^{\text {th }}$ century. Despite an overall low level of religious practice, especially among followers of the Church of England, religion remains important in the public space and in social debates, as exemplified by the compulsory teaching of religious education in State schools. Whereas identities are mainly defined along racial terms for Whites and Afro-Caribbeans, South Asian identities tend to be drawn along religious lines.

As compared to the US, immigration occupies a very different position in British history and British collective representations. The debates and policies regarding immigration have been shaped bearing in mind the importance of Commonwealth immigrants. They combine an increasingly restrictive immigration legislation and policies promoting the integration of migrants and the coexistence of the different communities. These policies have been used to legitimize the legislative stance: in other words, to ensure the successful integration of already settled immigrants, further immigration had to be stopped. Immigration became a political issue much earlier than in France, immigrants being confronted to racism and discrimination from the local population and the institutions (Lapeyronnie 1993).

If a large consensus was achieved as early as the 1960s on immigration policy, policies of management of the diversity introduced by immigration were-and still are-the subjects of heated debates. The initial policy of assimilation was quickly replaced by an ideal of integration that had to be achieved through the promotion of racial equality. Discrimination based on racism (both institutional and social) was identified as the major threat to the integration of immigrants and to social peace (Crowley 1994). Anti-racism is therefore an important component of the Race Relations legislation: racial discrimination was made illegal, equal opportunity in the access of ethnic minorities to public services and employment was promoted and new resources and powers were allocated to local authorities to enforce this policy. This had several consequences: racial (meaning ethnic) categories were created and one had to belong to pre-defined communities in order to benefit from the legislation. To understand on which basis ethnic categories have been constructed, let us examine the Mandla case. In 1979, the headmaster of a local private school refused to admit a Sikh boy unless he removed his turban to comply with rules about the school uniform. The Sikhs viewed it as indirect racial discrimination as defined by the 1976 Race Relations Act, and referred the case to the newly created Commission for 
Racial Equality, which then appealed to the House of Lords. Interestingly, the crux of the matter lied in establishing whether Sikhs were an ethnic/racial group or not, as only groups defined along ethnic lines and not merely on a religious basis could benefit from the 1976 Act. Ultimately, the Lords stated that Sikhs were indeed an ethnic group and made ethnicity the basis of collective identification and mobilization (Crowley 1994). According to another provision of the Race Relations legislation, local authorities were entrusted with the implementation of this policy. Accordingly, the competition for resources and for recognition amongst ethnic groups occurs mainly at the local level. The local authorities which are in charge of education and social services leave it to voluntary and community organizations to provide adequate service. These organizations entirely depend on annual grants from local authorities and enter thus in a fierce competition. Indeed 'rights and resources are claimed in the name of communities that must compete with each other' (Baumann 1996).

Since it lies on an opposition to racism, multiculturalism recognizes the right of ethnic communities to maintain separate cultures. Ethnic communities are hence defined by reference to reified cultures, which are in turn characterized by their internal homogeneity and binding. Unlike Whites and West Indians, South Asians have been encouraged to identify and mobilize along religious lines. British multiculturalism has therefore resulted in the politicization and ethnicization of these affiliations, in a way clearly reminiscent of colonial policies (Beckerlegge 1991).

As for France, in sharp contrast with the US, immigration holds a marginal role in the national ideology: traditionally, France does not perceive itself as a country of immigration (Schnapper 1991). And in contrast with its early politicization in the UK, from 1945 to the mid-1970s, immigration remained solely linked to economic requirements: it was central to French economic development, but remained very marginal in political debates (Lapeyronnie 1993, Weil 1991). But once labor migration was curbed, again for economic reasons, and the first wave of migrants gave way to the arrival of their family, France was confronted 15 years later with the same issues as in the UK, namely the integration of its migrant population. The French model of integration is usually described as universalistic and egalitarian, based on the ideal of republican individualism that rejects any public expression and recognition of cultural diversity (Lapeyronnie 1993). Cultural assimilation is supposed to be achieved on an individual basis, as the republican model does not acknowledge ethnic communities or any other intermediary social body between the State and individuals. Particular identities, considered as an obstacle to social progress, are to be abandoned. The contemporary rendition of the concept of laïité, epitomized for instance by the 2004 Act which banned the wearing of religious signs in State-run schools, ${ }^{12}$ is regarded as the prime instrument of republican integration: religion is to be confined to the private sphere and public expressions of faith (as the wearing of Islamic headscarves or Sikh turbans) are considered as a threat to the entire republican framework.

\section{Ethnic entrepreneurs: key players in the relationship building process}

37 If exogenous factors, like local contexts, are important in order to understand the complex intricacies at play in inter-ethnic relationships, so are more endogenous factors. 
Among them, leadership plays an important role: ethnic entrepreneurs are often crucial actors in either building bridges or widening gaps between sub-groups in the larger South Asian communities.

Host societies tend to transform the resources of migrants: some identities are devaluated and relegated to the private sphere, new economic opportunities appear, communities regroup along ethnic or religious lines to conform to the expectations of the State. As a result, potential entrepreneurs are offered a new set of resources that vary from one country of migration to the other. And identity becomes one of the resources that can be mobilized by the entrepreneurs.

The migration process as such creates the ground for the emergence of ethnic leaders or entrepreneurs. Their emergence can first be seen as an answer to the need of newly arrived migrants. For instance, when Pakistani men first landed in the UK, most were poorly-educated and could hardly speak English. They were therefore at loss in dealing with British institutions and so they turned to community members for help. In this context, anyone who was educated, had a good knowledge of English and was seen as being able to deal with British authorities, could easily achieve a position of influence, and hence be promoted to the status of a 'leader' (Shaw 1988: 138). After the phase of settlement was completed, the need for patrons did not subside, as new needs arose in response to the sense of disruption and marginalization due to the migration process. Maintaining ethnic and religious traditions and recreating a 'Pakistani community' became very important (Shaw 1988: 141-4). People who were able to 'organize' the community and set up institutions that would help perpetuating these traditions were fairly easily invested with authority within the community. As a result, new types of leaders, like imams and Sufi pirs, came to play a decisive entrepreneurial role, as the mobilization against Salman Rushdie revealed (Blom 1999).

Beyond ethnicity, religion and place of immigration, a similar phenomenon exists amongst other South Asian communities in the UK and elsewhere, including amongst educated, prosperous and fairly well integrated migrants. Such is the case in the United States or in Canada, where feelings of stigmatization and uprooting are experienced, no matter how successful the migrants are in their host societies. They also express similar needs for desi representatives that will help them maintain their ethnic heritage.

However, it is interesting to note that this tendency is particularly acute in countries which promote multiculturalism. It is much less visible in countries where integration at the individual level, like France, is called for. Indeed, multiculturalism encourages the construction of a public ethnic identity instead of a purely private one (Taylor 1992). This publicization can take various forms, like ethnic parades, ethnic awareness weeks, endowed chairs in universities and political lobbies. But, migrants are also submitted to pressures in host-societies to organize into groups that are culturally 'homogenous' and to have ethnic leaders as spokespersons for the community. As Kurien rightfully notes, 'the need to have a distinctive, coherent heritage puts pressure on members of ethnic groups to be ethnic in certain formulaic ways, including constructing a monocultural homeland in order to be part of a multicultural society' (Kurien 2004: 365). This in return can have serious implications on inter-ethnic relationships amongst South Asians, since leaders re-appropriate the prevalent notions of the host society and tend to promote essentialist and exclusivist conceptions of ethnicity, that do not leave much room for the Other, including the Other South Asian. Beyond the construction of exclusionist identities, another point to be noted is that unity is not only seen as a primordial 
prerequisite for any kind of influence within the community as well as in the host-society but also as a form of 'moral obligation' upon the community (as both a reaction to Partition and to the fitna tradition, a major feature of power-relationships in the Subcontinent, marked by constant shift of allegiance and alliances (Jaffrelot 1998: 113-45). However, South Asians have been characterized by a high propensity for internal divisions which decrease the effective impact of any single group whatever be its agenda.

The migration process leads some migrants to yearn for positions of leadership, seen as a compensation for the downward mobility that many of them experience. This longing for influence is stronger in multicultural societies where leaders of ethnic groups can become political actors, albeit usually only at a local level. Hence, this logic often encourages potential leaders to adopt positions that will ensure them both a status within the community and acceptance as legitimate representatives from the host society, even if these positions are defined along narrow ethnic or religious lines. For example, Pakistani leaders in the UK tend to seek influence by using the emotional issue of Islamic values (Shaw 1988: 143), whereas Indian Hindu representatives in the United States use redefined versions of Hinduism, (mostly) along Hindutva ${ }^{13}$ lines, to gain power within the community (Kurien 2004). For many self-styled Pakistani spokespersons, the use of Islamic references is seen as the right way of gaining the support of migrants who mostly look for means of curbing acculturation. For some Indian Hindu activists in the United States or Canada, and particularly for the supporters of Hindutva, a somewhat homogenized version of Hinduism can have a unifying effect in an alien land. Besides, as Jayant Lele notes in reference to the Canadian context, the label 'Hindu' has the 'advantage' of avoiding to have to deal with the compromising problems of the Sikhs ${ }^{14}$ and the Muslims (Lele 2003: 94). This may adversely affect the inter-ethnic relationships amongst South Asians, as leaders from all sides, neglecting the huge diversity of their home countries, tend to promote essentialized and exclusionist conceptions of their own cultures, in order to have access to resources in the double system of relations in which they operate: status amongst fellow migrants, political power and recognition from the host-society.

43 As opposed to the United States and the United Kingdom, where the settlement process has already taken place in the past decades and where there is a sizeable elite, most South Asian migrants in France still belong to the first generation and primarily hail from underprivileged social categories, with a fairly low educational background..$^{15}$ This situation has considerably hampered the leadership formation process as most migrants are still busy settling down and have a low visibility. While this pioneer stage and the profile of South Asian expatriates explain the strength of economic ties over other forms of bonding (see Chatterji in this volume), it does not account alone for this relative lack of leadership. The local context does indeed play a crucial role. The French model of integration does not encourage any type of mobilization at the community level, and hence do not officially recognize community leaders as such. However, in some conflictual cases (like the 'veil affair' for young Muslim girls and the turban issue for Sikh schoolboys), the French government has been confronted with the need for 'ethnic representatives'. Interestingly, in the case of the Sikhs, despite the official policy of laïcité, the representatives they have reached for are hailing from the local gurudwara. As for the Muslims (who are mostly from North and Sub Saharan Africa), the French authorities have lately engaged in a process of looking for 'legitimate' leaders in response to various 'challenges' (the hijab, and the perceived threat of fundamentalism, for instance). But this 
process is fraught with hurdles not only because of the internal diversity of Muslims but also because there are competing leaderships that are either recognized (or even nominated, as a legacy of the colonial period) by the French government, or by the 'community', but hardly ever by both.

In other words, depending on their countries of settlement, ethnic entrepreneurs mobilize the resources that are locally available: they form lobbies in the case of the United States (Mohammad-Arif 2000, Therwath in this volume), or opt for racial categorizations in the case of the UK. Accordingly, community leaders define the groups that they can mobilize.

The situations described above seem to suggest that a diasporic situation combined with migration to a multicultural society is bound to reinforce the cleavages between South Asians rather than bridge them. However, the picture does not look as grim: ethnic politics can also be promoted in progressive ways as the increasing dynamism of peacemaking South Asian organizations in North America and the UK reveals.

\section{Beyond confrontation, the emergence of a diasporic South Asian identity?}

South Asian diasporic subjectivities are fashioned as much by confrontation, violence or competition as by cooperation, solidarity and peace-making. This second strand of diasporic activism tends to be neglected by social scientists who have usually focused on the first aspect (except for Gayer 1998, Shain 1999), although both are interconnected.

The experience of migration has also fostered a common South Asian identity that transcends national, ethnic or religious cleavages. This pan-ethnic, inclusive type of identification emerges at first as an exo-definition by the host society, whose representations, categorizations and policies tended to lump together people from the sub-continent. The experience of racism, discrimination and marginalization has been particularly important, especially in the UK where the colonial legacy has greatly impinged on patterns of integration and inter-ethnic relations of the former colonized communities (see Moliner in this volume). This is also true of the post-9/11 situation in the US, as explained by Mohammad-Arif in this volume. Through censuses for instance, multicultural approaches have also led to the formation of new categories like South Asians in the US or Asians in the UK.

These perceptions from the host society are reappropriated by the diasporic communities, mostly by the second or third generation and an ascribed type of identification becomes an asserted one. Here the generation divide is clearly important: the youth, born and/or brought up in the host country, tends not to support the ethnoreligious or national divisions that they associate with their parents' generation, these 'uncles and aunties' mentioned by Therwath in this volume (although communal and fundamentalist organizations do recruit among sections of the youth). The trauma of Partition is still very present for the first generation of migrants and influences their representations of and relations to the South Asian Other. As in South Asia itself, the memory (both individual and collective) of these tragic events is transmitted to the second generation, particularly amongst Punjabis, but not to the third generation. If it still means something at all to the youth, Partition operates as a negative point of 
reference and encourages them to transcend the divisions and promote cooperation both in South Asia and in the diaspora. victories, with the banning of Sewa International in the $\mathrm{UK}^{16}$ or with the anti-Modi campaign (see Mohammad-Arif, Therwath in this volume), preventing him to enter the US. However, their real impact within their own communities tends to be rather limited: their following is mostly restricted to intellectual, academic and militant circles and their mobilization potential can in no way compete with their opponents. Their legitimacy to speak for the 'silent majority' remains to be established.

\section{The contributors}

54 In his contribution, Laurent Gayer reflects on the complexity to investigate on diasporic constructions of otherness (hence the paucity so far of empirical studies), as they are remarkable for their plurality and their volatility, in interaction with multiple contexts, 
local and transnational ones. Breaking away from reified conceptions of diaspora and their homeland, he stresses the dynamic dimension of diasporic identifications, while exploring local patterns of conflict and cooperation amongst South Asians in Southall. He demonstrates in particular how internal and external group boundaries are constantly questioned and challenged, be it towards a diasporic reinvention of communalism or the promotion of commonalities and of a pan-ethnic identity.

Miniya Chatterji, in the only article of this volume on France, examines how in Paris' socalled 'quartier indien', an area of intense migrant economic activity, community boundaries are being drawn among South Asian Muslims. She attempts to identify how 'sub-groups' are being redefined in migration, by tracing out the nature and depth of bonds and bridges shared by South Asian Muslims. She argues that, at such an early stage of settlement, economic activity seems more prevalent in defining these internal group boundaries than religion, national origin or language.

Christine Moliner focuses on Sikh representations of the Muslims and the relationships between those two groups sharing a common regional identity, both in the Sub-continent and in the diaspora. She does so diachronically, arguing that historical constructions of the Muslim as the Other (often, but not always, as the enemy) have been instrumental in Sikh identity formation process, since the $18^{\text {th }}$ century onwards. And synchronically, she traces the reshaping of these representations in the post-colonial UK that is home to important Sikh and Muslim populations and the ways they impact on inter-community relationships.

In her article, Aminah Mohammad-Arif examines the inter-ethnic relationships among South Asian diasporas in the United States, focusing more particularly on Hindus and Muslims, both Indians and Pakistanis. She argues that the importance of religion in the redefinition of individual and community identities combined with the settlement in a multicultural society, like the United States, has implications on the relationships between South Asians, as it has tended to (re)create cleavages. However, the proponents of exclusionist identities have been increasingly facing competition from secular forces, whose constructions of identities obey to different logics and repertoires that go beyond religion, and are inclusive of all communities to the extent of calling into question the borders drawn by History.

Ingrid Therwath addresses here the issue of Indian-American lobbies in the United States: their growing influence has been widely reported in the (ethnic) media, but even more striking are their internal divisions, giving way to the constant formation of new groups (a phenomenon known among South Asians as the 'everybody wants to be president syndrome'). In the face of these divisions, Islamophobia has provided a unifying force, whose roots can be found in the articulation between local and transnational factors: on the one hand the support to the Hindu nationalist ideology in the context of the (American) war against terrorism, on the other hand the furthering of the India-Israel-US strategic partnership.

\section{Conclusion}

While most contributors to this volume agree that the redefinitions of identities in a diasporic setting have had fairly adverse implications on inter-ethnic relationships, a common line of argument between the different contributions is the importance of local 
contexts in (over)determining the bonding and bridging process amongst South Asians. Conceptions of foreigners, classification patterns, institutional frameworks, as well as migration policies and agendas of each country are all crucial elements that need to be taken into account (Massicard 2005: 279). Some countries indeed encourage mobilization (whether along sectarian or progressive lines) on a community basis (namely multicultural societies), while others do not officially recognize communities as such, like France, and hence the issue of inter-ethnic relationships is not endowed with the same importance. But in France too, contradictions may surface as this society has been increasingly facing a tension between principles of assimilation of minorities at the individual level and policies towards more recent migrants that partly call into question these very principles, like affirmative action. At any rate, local dynamics are essential in the understanding of some of the identity investments and positions that are at stake (Massicard 2005: 274), as they influence the bonding or 'breaking' process within communities.

But not negligible either is the role played by the length of the migration process as well as by the social background of expatriates, as the degree of settlement in the host-society and the presence and visibility of an elite have an impact on the leadership formation, and related to it, on the community formation.

61 At any rate, all these groups, beyond their ideology, also operate in a double framework, articulating transnational interests with local concerns. As a result, though South Asians are far from impervious to events taking place in their home-societies, the inter-ethnic relationship issue in the diaspora obeys to a specific dynamic, related to a whole range of factors that goes well beyond a mere replication of the conflicts taking place in the Subcontinent.

\section{BIBLIOGRAPHY}

Anderson, Benedict (1983) Imagined Communities, London: Verso.

Anderson, Benedict (1998) The Spectre of Comparisons: Nationalism, South East Asia and the World, London: Verso.

Appadurai, Arjun (1996) Modernity at Large: Cultural Dimensions of Globalization, Minneapolis: University of Minneapolis Press.

Awaaz-South Asian Watch Ltd (2004) In Bad Faith? British Charity and Hindu Extremism.

Ballard, Roger (ed) (1994) Desh Pardesh: The South Asian Presence in Britain, London: Hurst.

Barth, Fredrik, (ed.) (1970) Ethnic Groups and Boundaries: The Social Organization of Cultural Differences, Boston: Little Brown \& Co.

Bates, Crispin (ed.) (2001) Community, Empire and Migration: South Asians in Diaspora, London: Palgrave, pp. 286-308.

Baubérot, Jean; Mathieu, Séverine (2002) Religion, modernité et culture au Royaume Uni et en France, Paris: Le Seuil. 
Baubérot, Jean (2004) Laïcité 1905-2005: entre passion et raison, Paris: Le Seuil.

Baumann, Gerd (1996) Contesting Culture: Discourses of Identity in Multi-ethnic London, Cambridge: Cambridge University Press.

Beckerlegge, Gwilym (1991) 'Strong Cultures and Distinctive Religions: the Influence of Imperialism upon British Communities of South Asian Origin', New Community, 17(2), January, pp 2001-210.

Blom, Amélie (1999) ‘Towards Global Belongings? Interpretive Communities, Minorities and Protests Against “The Satanic Verses”, in Andrew Geddes \& Adrian Favell (eds.), The Politics of Belonging, Avebury (UK): Ashgate, pp. 192-208.

Brass, Paul (1991) Ethnicity and Nationalism: Theory and Comparison, New Delhi: Sage.

Burlet, Stacey \& Helen Reid (1995)'Cooperation and Conflict: the South Asian Diaspora after Ayodhya', New Community, 21(4), October.

Crowley John (1994) Immigration, 'relations raciales' et mobilisations minoritaires au Royaume-Uni, PHD dissertation, Paris: Institut d'études politiques.

Gaborieau, Marc (2001) 'Identités musulmanes, orientalisme, ethnographie : Faut-il réhabiliter les auteurs coloniaux?', in Jean-Luc Racine (ed.), La question identitaire en Asie du Sud, Paris: Éditions de l'EHESS, pp. 71-89 (Collection Purusartha, 22).

Gaborieau, Marc (2003) 'La partition était-elle inéluctable?', L’Histoire, 278, juillet-août, pp. 84-87 (numéro spécial Les mystères de l'Inde. Du Bouddha à Gandhi).

Gayer, Laurent (1998) Diaspora indo-pakistanaise et régulation de la conflictualité à Londres et à Paris, DEA dissertation, Paris: Institut d'études politiques.

Hobsbawm, Eric; Ranger, Terence (eds.) (1983) The Invention of Tradition, Cambridge: Cambridge University Press.

Horowitz, Donald (1985) Ethnic Groups in Conflict, Berkeley: University of California Press.

Jaffrelot, Christophe (1993) Les Nationalistes hindous, Paris: Presses de la FNSP.

Jaffrelot, Christophe (1998) La démocratie en Inde: religion, caste et politique, Paris: Fayard.

Kurien, Prema (2001) 'Religion, Ethnicity and Politics: Hindu and Muslim Indian Immigrants in the United States', Ethnic and Racial Studies, 24(2), March, pp. 263-93.

Kurien, Prema (2004) 'Multiculturalism, Immigrant Religion, and Diasporic Nationalism: The Development of an American Hinduism', Social Problems, 53(3), pp. 362-85.

Lapeyronnie, Didier (1993) L'individu et les minorités: La France et la Grande Bretagne face à leurs immigrés, Paris: PUF.

Lacorne, Denis (1997) La crise de l'identité américaine: du melting-pot au multiculturalisme, Paris: Fayard.

Lacorne, Denis (ed.) (2006) Les Etats-Unis, Paris, Fayard.

Lele, Jayant (2003) 'Indian Diaspora's Long Distance Nationalism: The Rise and Proliferation of 'Hindutva' in Canada', in Sushma Varma \& Radhika Sheshan (eds.) Fractured Identity: the Indian Diaspora in Canada, Delhi: Rawat Publications, pp. 66-119.

Lemarchand, Philippe (ed.) (1997) Atlas des Etats-Unis: Les paradoxes de la puissance, Paris: Complexe. 
Marienstras, Elise (1997) Nation et religion aux Etats-Unis, in Patrick Michel (ed.), Religion et démocratie, Paris: Albin Michel.

Massicard, Elise (2005) L'autre Turquie, Paris: Presses Universitaires de France.

Mathew, Biju \& Prashad, Vijay (2000) 'The Protean Forms of Yankee Hindutva', Ethnic and Racial Studies, 23, pp. 516-34.

Mazumdar, Sucheta (2003) 'The Politics of Religion and National Origin: Rediscovering Hindu Indian Identity in the United States', Antinomies of Modernity: Essays on Race, Orientalism, and Nation, pp. 223-60.

Metcalf, Thomas (1995) Ideologies of the Raj, Cambridge: Cambridge University Press.

Modood, Tariq; Werbner, Pnina (eds) (1997) The Politics of Multiculturalism in the New Europe: Racism, Identity and Community, London \& NY: Zed Books.

Mohammad-Arif, Aminah (2000) 'The Lobbying Game of the Indian and Pakistani Diasporas in the U.S', http://www.ceri-sciences-po.org.

Mohammad-Arif, Aminah (2001) 'Relationships between Hindus and Muslims in the United States: Mlecchas versus Kafirs? in Crispin Bates, ed., Community, Empire and Migration: South Asians in Diaspora, London: Palgrave, pp. 286-308.

Pandey, Gyanendra (1990) The Construction of Communalism in Colonial North India, Delhi: Oxford University Press.

Prashad, Vijay (2000) The Karma of Brown Folk, London \& Minneapolis: University of Minnesota Press.

Rajagopal, Arvind (2000) 'Hindu Nationalism in the US: Changing Configurations of Political Practice', Ethnic and Racial Studies, 23, pp. 467-96.

Sabbagh, Daniel (2004) 'Nationalisme et multiculturalisme', Critique internationale, 23, avril. Sabrang Communications Private Limited (2002) The Foreign Exchange of Hate: IDRF and the American Funding of Hindutva, Mumbai: Sabrang.

Schnapper, Dominique (1991) La France de l'intégration: Sociologie de la nation en 1990, Paris : Gallimard.

Schnapper, Dominique (1998) La relation à l'autre: au cour de la pensée sociologique, Paris: Gallimard. Schnapper, Dominique; Bordes-Benayoun, Chantal (2006) Diasporas et nations, Paris: Odile Jacob. Shain, Yossi (1999) Marketing the American Creed Abroad: Diasporas in the US and their Homelands, Cambridge: Cambridge University Press.

Shaw, Alison (1988) A Pakistani Community in Britain, Oxford: Basil Blackwell.

Sheffer, Gabriel (2003) Diaspora Politics: At Home Abroad, Cambridge: Cambridge University Press. Singh, Gurharpal (2005) ‘British Multiculturalism and Sikhs', Sikh Formations, 1(2), December, London: Routledge, pp. 157-73.

Subrahmanyam, Sanjay (1996) 'Before the Leviathan: Sectarian Violence and the State in PreColonial India', in Kaushik. Basu, \& Sanjay Subrahmanyam, eds, Unraveling the Nation. Sectarian Conflict and India's Secular Identity, Delhi: Penguins Books India(P) Ltd, pp.44-80.

Taylor, Charles (1992) Multiculturalism and the Politics of Recognition, Princeton: Princeton University Press. 
Van der Veer, Peter (1994) Religious Nationalism: Hindus and Muslims in India, Berkeley: University of California Press.

Van der Veer, Peter (1995) Nation and Migration: The Politics of Space in the South Asian Diaspora, Philadelphia: University of Pennsylvania.

Varma, Sushma J. \& Sheshan, Radhika (eds.) (2003) Fractured Identity: The Indian Diaspora in Canada, Jaipur and New Delhi: Rawat Publications.

Varshney, Ashutosh (2003) Ethnic Conflict and Civic Life: Hindus and Muslims in India, Delhi: Oxford.

Visram, Rozina (1986) Ayahs, Lascars and Princes, London: Pluto.

Weil, Patrick (1991) La France et ses étrangers. L'aventure d'une politique de l'immigration, 1938-1991, Paris : Calmann-Lévy.

Zaman, Muhammad Qasim (1998) 'Sectarianism in Pakistan: the Radicalization of Shi'a and Sunni Identities’, Modern Asian Studies, 32(3), pp. 686-716.

\section{NOTES}

1. Communalism as such is the propaganda or the effective action led by the members of a religious community against the members of another community.

2. With a particular focus on Indians, Pakistanis and Bangladeshis.

3. During a meeting of French researchers with Indian Prime minister Manmohan Singh and former Minister for External Affairs, Natwar Singh reacted, to a question we asked Manmohan Singh about the Indian diaspora, by saying that according to him, Indians did not represent a diaspora, as they still had a home-country. This certainly provides an interesting insight about the relationship between the Indian government and its expatriates. We will nonetheless use the term 'diaspora', despite its increasingly indiscriminate usage to refer from its original meaning of dispersion (of the Jews) to any group of dispersed people, and understand it here as a dynamic process and not as a fixed category (for further elaboration on the concept, see Gayer in this volume).

4. We are using here the plural as South Asians form very heterogeneous communities.

5. Although we understand here ethnicity as a social process, and not as a cultural or biological given, we must keep in mind the predominantly static, primordial understanding of the term in public discourse (particularly among 'ethnic entrepreneurs' themselves).

6. Vishva Hindu Parishad, see Mohammad-Arif in this volume.

7. Jama'at-i Islami. See Mohammad-Arif in this volume.

8. These are estimates as many of the South Asian migrants, particularly in Western countries, are undocumented.

9. The Hindu nationalists in particular (Sabrang 2002)

10. As in Austria, Belgium or the Netherlands where there is a coalition of ethnic leaders in government, group proportionality in decision-making, mutual veto, and autonomy in such fields as personal laws, education and language. See Lijphart in (Varshney 2003: 37).

11. As there are also migrants coming from the French West Indies, Reunion Island, Mauritius and Madagascar.

12. The original definition of laïcité refers to a legal and ideological framework that guarantees, through the separation of Churches and the State, the independence of religious organizations vis-à-vis political power and secondly freedom of conscience by that same power. This framework was designed at the beginning of the $20^{\text {th }}$ century as an attempt to limit the power of the Catholic Church which, along with the Royalists, was trying to destabilize the young and 
fragile regime of the third Republic. One should stress that this was done not in a militant spirit (there was no intent to crush organized religions) but in a compromising frame of mind. See Jean Baubérot 2004.

13. The doctrine of Hindu nationalists.

14. This is particularly true for Canada, and less so for the United States, as in Canada, there is a more 'visible' Sikh community, among which a minority has indulged in violence in its support for the Khalistani movement.

15. The exceptions are migrants from Pondicherry and the tiny minority from Bengal, who include a sizable number, the latter in particular, of fairly successful people.

16. A sister organisation of the Hindu Swayamsevak Sangh (the UK branch of the RSS), Sewa International posed as a charity and collected funds in the UK and elsewhere purportedly to help the Gujarat earthquake victims in 2001. As revealed by an inquiry, the funds were actually used for RSS activities in India (see the report by Awaaz-South Asia Watch Ltd, www.awaazsaw.org/ ibf/index.htm) 